\title{
Osmanlı Mimarisinde Kullanılan Nebati Motiflerin Modern Soyut Türk Resmine Katkıları ${ }^{1}$
}

\author{
Tuncay ÇIÇEK \\ Dr. Öğr. Üyesi, Iğdır Üniversitesi, \\ Fen Edebiyat Fakültesi, Sanat Tarihi Bölümü \\ alpago_25@hotmail.com \\ Orcid ID: https://orcid.org/0000-0002-6833-6462
}

\begin{abstract}
Öz
Geleneksel sanatlar gerçekleştirildikleri bölgelere, ülkeye ve yapanların tecrübesi, bilgisi ve kullanmış oldukları malzemelere göre farklılık göstermektedir. Tarih öncesi devirler itibariyle Anadolu'da sanatın geleneksel oluşumu, içinde bulunulan sürecin içindeki pek çok sosyolojik, ekonomik ve siyasal faktörün etkisinde kalmıştır. Osmanlı döneminde İslam sanatının oluşumu da Osmanlı'nın bütün dönemlerinde devam etmiş ve her yerde kendisini göstermiştir. Özellikle mimari alanda o günden bugüne kalan sanatsal unsurların hepsinde döneme ait özel teknik ve motifler görülmektedir. Türkiye'de Cumhuriyet'in ilanından sonra ortaya çıkan "modern" kavramı ise bütün topluma ve sanata etkide bulunmuştur. Bu süreçte pek çok sanatçı Batı etkisinde kalan farklı resim tekniklerini denemiş ve geleneksel sanatları bir bakıma göz ardı etmiştir. Fakat zaman içerisinde resme çok farklı tekniklerin girmesi ve özellikle modern soyut Türk resminin de oluşumuyla geleneksel sanatlar kullanılarak resimde sentez oluşturan teknikler kullanılmaya başlanmıştır. Bu çalışmada modern soyut Türk resmine Osmanlı mimarisinde kullanılan nebati motiflerin etkileri incelenmiştir. $\mathrm{Bu}$ inceleme esnasında nebati motiflerin kullanımı, Osmanlı mimarisindeki yeri, tanımı, soyut Türk resmi ve son olarak da soyut Türk resmindeki nebati motif örneklerine yer verilmiştir.
\end{abstract}

Anahtar Kelimeler: Nebati Motif, Soyut, Resim Sanat1, Türk Resmi.

\footnotetext{
${ }^{1}$ Makale Geliş/Kabul Tarihi: 01.06.2021 / 02.08.2021

Künye Bilgisi: Çiçek, T. (2021). Osmanlı Mimarisinde Kullanılan Nebati Motiflerin Modern Soyut Türk Resmine Katkıları. Kahramanmaraşs Sütçü İmam Üniversitesi Sosyal Bilimler Dergisi, 18(2), 895-908. DOI: 10.33437/ksusbd.946393
} 


\title{
The Contribution of Nabataean Motifs Used in Ottoman Architecture to Modern Abstract Turkish Painting
}

\begin{abstract}
Traditional arts differ according to the regions in which they are performed, the country and the experience, knowledge and materials they use. As of prehistoric times, the traditional formation of art in Anatolia has been affected by many sociological, economic and political factors in the current period. The formation of Islamic art in the Ottoman period also continued in all periods of the Ottoman Empire and showed itself everywhere. Especially in the field of architecture, special techniques and motifs belonging to the period are seen in all of the artistic elements that have survived since that day. The "modern" concept that emerged in Turkey after the proclamation of the Republic had an impact on the whole society and even the arts. In this process, many artists tried different painting techniques under the influence of the West and ignored traditional arts in a way. However, with the introduction of many different techniques into painting over time and especially the formation of modern abstract Turkish painting, techniques that create synthesis in painting by using traditional arts have begun to be used. In this study, the effects of Nabataean motifs used in Ottoman architecture on modern abstract Turkish painting were examined. During this study, the use of vegetable motifs, its place in Ottoman architecture, its definition, abstract Turkish painting and finally, examples of vegetal motifs in abstract Turkish painting are included.
\end{abstract}

Keywords: Nebati Motif, Abstract, Painting Art, Turkish Painting.

\section{GíRIŞ}

Pek çok disiplinin bir araya gelişiyle sanat oluşmaktadır. Bu disiplinler arasında en fazla öne çıkan şüphe yok ki resim sanatıdır. Resim sanatı, insanlığın hedefleri bağlamında ortaya çıkmış olup günümüze dek pek çok aşamadan geçip evrimleşen bir paylaşım aracıdır. İlk çağlarda duvarlara yapılan çizimler ilk resim sanatı örnekleri sayılmıştır ve o dönemin sanat ihtiyacına yanıt vermiştir. Bu bağlamda o dönemde insanlar pek çok gereksinimini avlanma yöntemleri, korkular, iletişim gibi duygu paylaşımı için mağara duvarlarına resimler aracılığıyla anlatmıştır. Sonraki yıllarda kişilerin inançları ya da dönemin sosyoekonomik sistemi resim sanatını da dönüştürmüştür. Gelişme evresinde zaman içerisinde ortaya çıkan dönüşüm sonucunda resim sanatı farklı noktalardan geçmiştir. Sanatçılar kızgınlık, nefret, aşk gibi pek çok duygusunu tuvallerine ya da kendilerini rahat ifade edebilecekleri araçlara yansıtmaya başlamışlardır. $\mathrm{Bu}$ 
durum sanatçıların daha yaratıcı ve özgün bir dil kullanımı konusunda onları daha cesaretli hale getirmiştir.

Benzer süreçleri Türk resim sanatı için de geçerli olmuş olmakla beraber Cumhuriyet'in ilan edilmesiyle beraber pek çok sanatçı Avrupa'ya eğitim almak üzere gönderilmiştir. Sanatçılar eğitim aldıktan sonra kendileri için farklı üslup tercihlerinde bulunup dünyanın her yerinde gelişme gösteren yeni eğilimlere karşı da kayıtsız kalmamışlardır. Dolayısıyla Türk resim sanatında ilk kez 1950 ve 1960'l y yllarda resimde soyut ve soyutlama anlayışları benimsenmiş olmakla beraber günümüzde de modern soyut resim yapan pek çok Türk ressama rastlama mümkündür.

Sanat eserleri hiçbir zaman kültürel olgulardan uzak kalmamıştır. Bu durum modern soyut Türk resmini de etkilemiş olup sanat eserlerinde geçmişe dönük motiflerin görülmesini sağlamıştır. Bu bağlamda pek çok Türk ressamın çalışmalarında Osmanlı mimarisinin motiflerini de görmek mümkündür.

Bütün bu bilgilerin 1şığında bu çalışmada Osmanlı mimarisindeki Nebati motiflerin modern soyut Türk resmine olan etkileri ele alınmıștır. Çalıșmada Nebati motif kullanan ressamlardan da örneklere yer verilerek konunun ifade edilmesi amaçlanmaktadır.

\section{Osmanlı Mimarisi ve Nebati Motifler}

Osmanlı mimarisinde bezeme sanatı bünyesinde tezyinat oluşturan nakışların çoğunun konularını tabiat oluşturmaktadır. Nebatinin kaynaklık ettiği nakışların ekseriyetinin bulunduğu nakışların arasında bulut motifi oldukça öne çıkmıştır. Mimari yapıların içerisinde en fazla tercih edilen süsleme, -"kütle ve hacimden çok"- nebati motifler olmuştur. "Sıraltı" çinilerinin gelişmesiyle beraber, Osmanlı'da çini sanatında da nebati temelli motifler gelişme gösterip artmıştır (Demiriz, 1979).

Romalılara ait olan manasına gelen "rûmî (Romî)" motifi, neredeyse tüm kaynaklar arasında Anadolu'ya bu bağlamda da Anadolu Selçuklu Devleti'ne mal edilmiştir. Kaynağı itibari ile hayvani mi yoksa nebati mi olduklarıyla ilgili olarak iki farklı görüş literatürde yer almaktadır. Bazı çevreler tarafından Türk sanatında palmet ve lotus şeklinde isimlendirilen nakışlar, geleneksel anlayış bağlamında çoğunlukla "rûmî" motifinin aradaki bir çeşidi şeklinde ifade edilmiştir. Rûmî motifinin sadece bir nakış değil bununla beraber bir üslûp şekli olduğu kabul edildiğinde, bahsi geçen motiflerin adlandırılmalarıyla ilgili daha net sonuçlar edinileceği düşünülmektedir. Benzer karmaşalardan Hatayî üslûbu için de bahsedilmektedir. Pek çok örnekte hayvani bir çıkışla dikkati çeken rûmî üslûbunun da palmet ve lotus benzeri farklı biçimlerinin nebati adlarla isimlendirilmesi de bir başka tezat ortaya koymaktadır (Güney, 2002). 
Türklerin çini sanatında nebati motifleri tercih etmesi, Osmanlı Devleti öncesinde Anadolu'da Selçuklularda ortaya çıkmıştır. İlk örnekler arasında "geometrik sahaları çerçeveleyen bir bordürcü” görüntüsü olmasına rağmen 8 . yüzyılın ikinci yarısı sonrasında çok daha zengin ve çeşitli kompozisyonlar ortaya çıkıp kısa sürede yaygın hale gelmiştir. Özellikle saray yapılarında kullanılması tercih edilen farklı tekniklerdeki çinilerin üzerinde çoğunlukla şekillerin çevresinde ya da köşelerindeki dolgular nebati motiflerle bezenmiştir. Bunların arasında bir haşhaş ya da nara çok fazla benzeyen natüralist nebati görüntüler olmakla beraber "palmet, lotus ve rumi" ismi verilmiş olan nebati motifler çok daha yoğun bir şekilde kullanılmıştır. Söz konusu nebati motifler hem tekli halde kıvrık ve bir dalın üstünde birleşmiş şekilde "lotus-palmet frizi" ya da "palmet" ve bunların iki tarafından çevrelenmiş çift Rumiler ile birleşik şekilde düzenlenmiş ve çeşitli bezemelerde yer almıştır. Bütün bunların bir arada kullanılmasıyla ortaya çıkan örneklerin o dönemde en çok mozaik çinilerde kullanıldığı görülmektedir (Bulut, 1994).

Genel olarak nebati motifler dendiğinde Osmanlı mimarisinde kullanılmış olan en yaygın bezeme akla gelmektedir. Pek çok bitkinin yaprak, çiçek ve sağlarının bu motif türü içinde değerlendirildiği ilgili kaynaklarda yer almaktadır. Nebati motiflerin büyük çoğunluğu hatayî üslûbundan oluşmaktadır. Doğu Türkistan'dan geldiği bilinen hatayî üslûbundaki bitkiler ileri seviyede üsluplu hale getirildiği için, örneklerde hangi bitkilerden ilham alınmak suretiyle çizilmiş olduğu net bir biçimde bilinmemektedir. Çeşitli tarihi kaynaklarda, söz konusu bezeme şekilleri ifade edilirken "yaprak (berg), gonca, gül ve hatayî” gibi çeşitli isimler kullanılmıştır (Gürsu, 1988).

Genel olarak Osmanlı mimari İslam kültürünü temel aldığı için İslami tarzda bezeme farklı kültürlerin mimaride kullanmış olduğu bezemelerden çok farklı bir seviyede gelişmiştir. Tasvirlerin ve betimleme anlayışının zaman içerisinde sınıflandırılmasının sonucunda İslami bezemelerin genellikle geometrik, yazı(hat) ve nebati motiflerle oluşmasına sebep olmuştur. Tercih edilen bezemenin türü ne olursa olsun, düzenlemelerin temelinde geometrik şekiller bulunmaktadır. Yazı ve nebati kökenli bezemelerin hemen hepsinde üçgen, çember, çokgen, dikdörtgen ve kare gibi geometrik şekiller kompozisyon oluşturmaktadır.

Desenlerin oluşmasını sağlayan motifler, çiçeklerin açılmış ve gonca halleri, ifade ve duruş biçimleri bağlamında "gonca, gül, hatayî ve yaprak" gibi pek çok alt sınıf kullanılarak ifade edilmektedir. Nebati düşünüldüğü gibi bir çiçeğin dik kesitindeki anatomik çizgilerin stilize edilmek suretiyle çizilmesi biçimini ifade etmeyip, çiçeğin anatomik yapısında şeffaflaştırma yaparak, mestane bir bakış yardımıyla üslûba çekilmesi ile oluşup bu şekli ifade etmektedir. Nebati çerçevesinde bahsedilen çiçekler, ilham kaynakları bağlamında, katmerli 
yapraklı, çanaklı, tek yapraklı ya da çanaksız olmak kaydıyla farklı şekiller ile tabir edilmektedir (Gürsu, 1988).

Nebati motif temelli alanda sayılan "penç motifi" ise çiçeklerden herhangi birinin görünümünün belirli bir üslupla biçimlendirilmiş halini ifade etmektedir (Birol ve Derman, 2004: 45). Bahsi geçen çiçeklerin isimlendirilmesi çizilmiş olan yapraklar sayesinde mümkün olmuş olup "Tek yapraklı (yek berk), iki yapraklı (dü berk), üç yapraklı (se berk), dört yapraklı (cihar berk), beş yapraklı (Penç berk), altı yapraklı (şeş berk)" şeklindedir. Desenin içerisinde büyüklüğü bağlamında hem yardımcı motif olarak hem de ana motif olarak tercih edilen penç motifinin, herhangi bir kısmından çıkabilen dallar gibi belirli yönler olmadığı için dalların başlangıç noktaları da desenin içindeki temel motif olarak kabul edilmektedir (Birol ve Derman, 2004: 47).

Nebatiler, Osmanlı bezeme sanatında temel motifler arasında yer almaktadır. Orta Asya'dan gelip Çin sanatı etkisinin altında gelişme gösteren doğa parçalarının kullanıldığı pek çok motif Nebati bünyesinde ele alınmaktadır. Çoğunlukla gerçekleri belli olmayacak şekilde stilize edilmek suretiyle tüm süsleme alanlarında kullanılmış olup gittikçe daha da önemli hale gelmiştir. (Güney, 2002: 42).

16. yüzyılın ilk yarısında "saray nakkaşbaşısı (sernakkaşı) Şahkulu" nebati motiflerin de içerisinde bulunduğu "hatayî üslûbu" için pek çok yenilik ortaya koymuştur. Yine aynı yüzyılın ikinci yarısında Şahkulu'nun öğrencisi olan "Kara Memi'nin" Hasbahçe'de ki çiçekleri bezeme sanatına eklemesiyle mimaride natüralist bir hareket tarzı ortaya çıkmış olup, bunların sonucunda pek çok nebati motif de mimariye eklenmiş ve özellikle de "şükûfe (çiçek) üslûbu" bulunmuştur.

Osmanlı'nın son dönemlerinde Batılı hareketlerin de etkisiyle yaygın hale gelen çiçek resimleriyle şükûfe tarzı birbirine karıştırılmamalıdır. Çünkü "şükûfe" tarzında kullanılan bütün çiçekler öz biçimleri korunmak suretiyle aslında "yarı üsluplu" bir halde görünmektedir. Aslında o dönemde mimaride tercih edilen çiçek resimlerinde "üslûplaştırma" hiç yapılmamış olup, başlı başına bir tablo olarak tasarlanan çiçek resimleri bir "tezhib üslûbu" içinde bezeyiciler arasında bir unsuru oluşturmanın ötesinde, resim sanatının içinde konumlandırılması gerekli olan bir başka konuyu ortaya koymaktadır.

Kanuni Sultan Süleyman Devrinde Şahkulu, "Osmanlı Saray Nakışhânesi'nde" o dönemde yeni kabul edilen bir bezeme tarzı olarak ortaya çıkıp gelişen "saz yolunun" ilk temsilcisi kabul edilmektedir. Kelime olarak saz "üslûp ve tarz" manasındaki yol ile bir araya gelip Osmanlı mimarisinin süsleme terimlerinin arasında zemin kısmı boyanmamış kağıtların üstüne bir fırçayla siyah mürekkep yardımıyla çizilen resmi tanımlamaktadır. İlgili resimde Şahkulu 
tarafından çizilmiş olup "Saz Yolu” üslubunun ilk ifade edildiği eserler arasında sayılmaktadır.

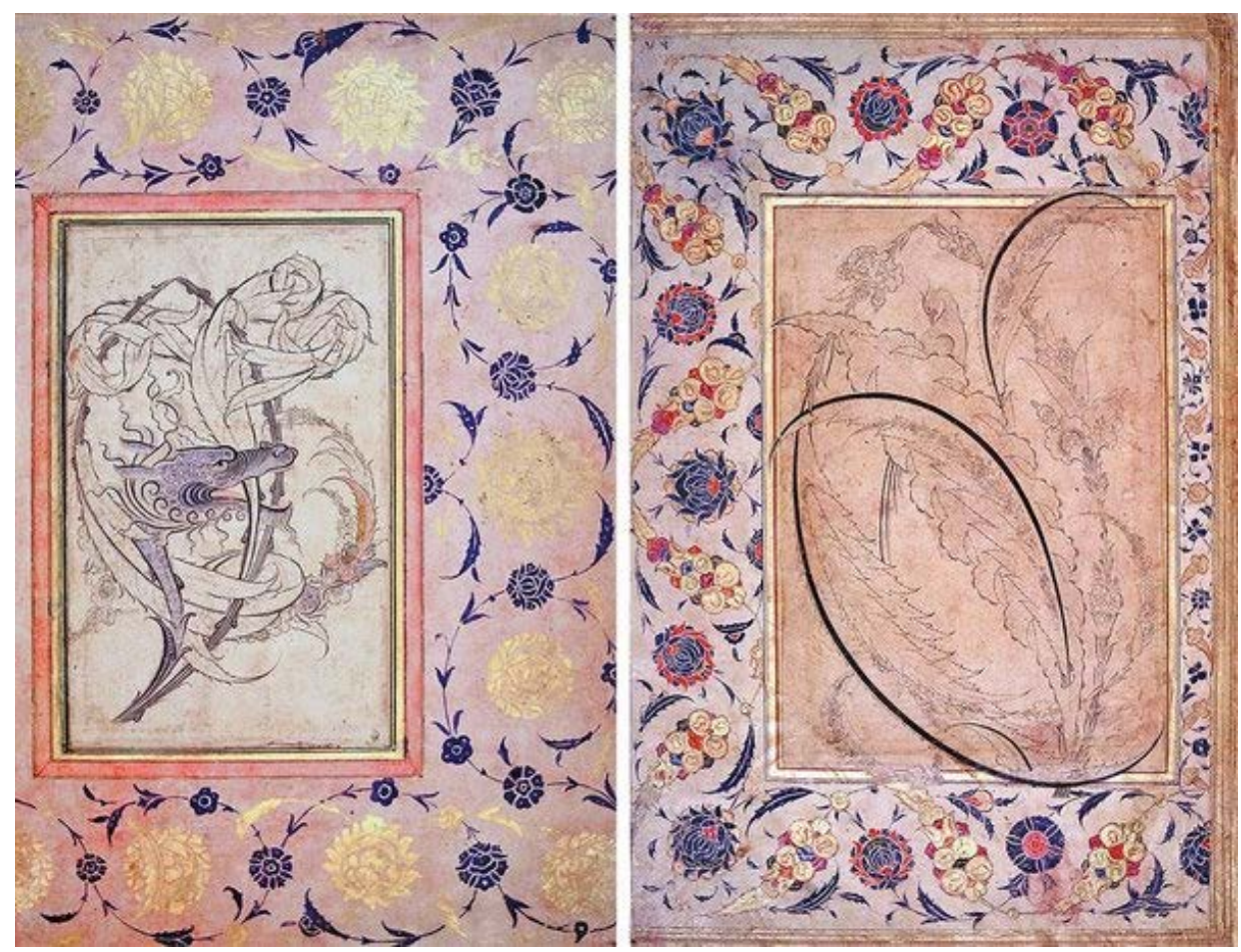

Resim 1. Şahkulu tarafından yapılmış saz yolu örneği

Şahkulu'nun öncüsü olduğu söz konusu "saz yolu" tarzı Osmanlı kitap sanatı bünyesinde hem de mimari alanda resmin ardından ihtişamı en fazla olan pek çok örneği de tezhip sanatı alanında vermiştir. 


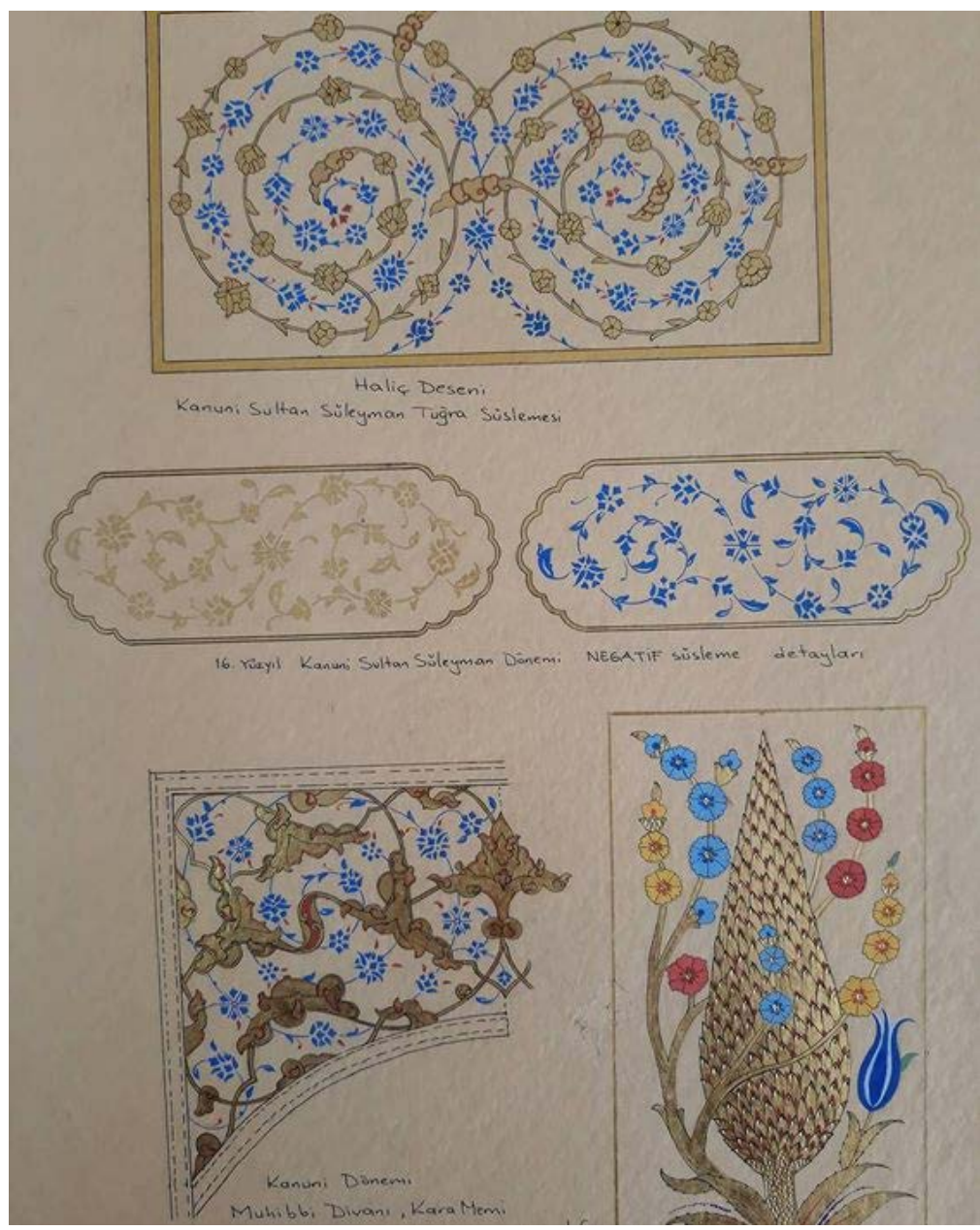

Resim 2. Osmanlı Dönemi’nde Kullanılan Nebati Süslemeler

\section{Türkiye'de Modern Soyut Resim Sanatı ve Nebati Motifler}

Türk resim anlayışı içerisinde, soyut ve soyut ekspresyonizme ilgi gösterilmesi, resimle ilgili kavramların yeni boyutlandırılmasını sağlamaktadır. Resim kompozisyonlarının hızlı şekilde oluşumu tuvallerin yüzeyinde bulunmalarını zorunlu hale getirmektedir. Sonuçta, bu durum bütün sanatçılar için ayrı bir firçayla çizgi dokusu, ayrı anlatım şekilleri anlamına gelmektedir (Kayapınar, 2013).

Genel hatlarıyla, Türk resim anlayışında özgünlüğün araştırılması uğraşı ile beraber bazen geleneksel, yerel, ulusal bazen de Batılı bir yaklaşım temelinde kullanılan motifler, resimdeki kompozisyonun yapısal bütünlüğünün içerisinde 
estetik bir işlevi barındırmıyorsa, yaratıcılığın önüne geçen bir aktarımdan daha ziyade ilerleyememektedir. Diğer yandan Batı veya Doğu sanatındaki herhangi bir şeyin direkt olarak kopyalanması bir diğer ifadeyle tekrar edilmesi sanatçıların çağdaş veya özgün olmasını engellemektedir. Resim sanatında yaratıcılık, sanatçı tarafından özel felsefeler geliştirilmesiyle resimle ilgili faktörlerin malzeme temelinde organik araştırma süreci içerisinde bulunmasını ifade etmektedir (Aslanapa, 2007).

Osmanlı Devleti'nin son dönemleriyle Cumhuriyet'in ilanıly beraber, Türk ressamlarının eğitim almaları maksadıyla Avrupa'da ki farklı şehirlere gönderilmesi Türk resim sanatının tarihi seyrinin değişmesini sağlamıştır. Türk resim sanatında Batılılaşma süreci içerisinde 1910 senesinde Kandinsky tarafından gerçekleştirilen ilk soyut kompozisyonlara ortaya çıkana dek Türkiye'de resim deyince akla gerçekçi, romantik, oryantalist ve akademik benzeri stillerin hâkim olduğu söylenebilecektir (Duben, 2007).

Türk resminin tarzı ne olursa olsun hepsinin temelinde doğa bulunmaktadır. Söz konusu y1llarda kurulmuş olan tüm grupların temelinin figüratif bir anlayıştan oluştuğunun söylenmesi doğru olacaktır. 1950'li yıllara dek Türkiye'nin sosyokültürel değişimlerinin de etkisiyle sanatta da değişimler olduğu söylenebilecektir. Bu bağlamda Cumhuriyet'in de ilan edilmesiyle beraber pek çok sanatçının yurt dışına gönderilmesiyle beraber Türk resmi modernleşme sürecine girmiştir (Kayapınar, 2013).

1960 yıllarında Türkiye'deki resmin genel tarzı soyut sanat akımlarının çevresinde gelişme göstermiştir. Bu dönemde Türk resim sanatı üzerinde etkisi olan söz konusu soyut akımların arasında bulunan ressamlar kendilerinin şekildeki bakış açılarını geliştirmek suretiyle söz konusu tarzların Avrupa'da ortaya çıkmış olan süreçlerinden daha farklı ve özgün olarak geliştiğini de ifade etmişlerdir. Sonrasında 1970 yılları süresince yeni eğilimlerin de ortaya çıkışıyla daha da fazla boyuta sahip olan bu anlayış ve diyalektik Türk resminde modernleşmenin döneme ayak uyduran bir resim anlayışının gelişmeye başladığını göstermektedir (Gültekin,1992: 17).

Ressam birlikleri ya da gruplaşmaların çok daha önemli hale geldiği bu süreçte, 1960 yıllarının ilk yarısında modern Türk resmi içerisinde "Mavi Grup" olarak isimlendirilen yeni bir ressam topluluğu da ortaya çıkmıştır. Fakat bu dönemde öne çıkan ressamlar arasında bulunan "Adnan Çoker, Sarkis Zabunyan, Tülay Tura (Börtecene/Oktay), Devrim Erbil ve Altan Gürman (1935-1976)” gibi isimlerin oluşturmuş olduğu resim sanatı açısından etkili olamayıp kısa bir süre sonra dağılmıştır. Aynı dönemde "Özdemir Altan, Ömer Uluç (1931-2010), Erol Akyavaş (1932-1999), Fethi Arda ve Burhan Uygur (1940-1992)” gibi isimler çok daha önemli ve etkili olmuşlardır. 1950 yıllarının ortaları itibariyle 
Türk resmi bünyesinde geniş bir tabana sahip olan modern soyut resim anlayışı zaman içerisinde özgün doğa betimlemeleriyle figüre yönelik anlayışı da geliştirmiştir. "Yeniler Grubu" olarak isimlendirilen ressam bünyesinde bulunanlardan bazılarının tuvallerinde de "soyutlama" yapan bir tavır ile ortaya konmuş doğa tasvirleriyle figürler, bu dönem içerisinde etkin olan ressamlar tarafından, kendilerinin öncesindeki "Halk Sanatı" kuşağı benzeri imge ve konularını hatta geleneksel Osmanlı mimarisinden almış oldukları ilhamı "döneme özgür" ve "farklı" soyut anlayışları da katarak resimlerinde bir araya getirip oldukça zengin bir tarzı ortaya koymuşlardır. İçinde bulunduğu dönem için entelektüel bir alan şeklinde kabul edilen soyut resim sanatına bir kök ve bir form bulma isteğiyle Anadolu temelli folklorik ve yerel unsurlar, halk estetiği üzerine eklenen bezeme, minyatür, çini, hat, kilim ve kaligrafi gelenekte kullanılan nebati motifler modern soyut Türk resmiyle buluşmuştur. Bununla beraber geometrik, lirik ve figürün öne çıkmadığı bu anlayış, o dönemde pek çok ressamla başlamış olup bugüne dek gelişerek ilerlemiştir (Çalıkoğlu, 2008: 11).

20. yüzyılda Türk resminde modernleşme dendiğinde ilk olarak Batılı resminin etkilerinden bahsedilmesi yerinde olacaktır. Bu durumun etkileri boya seçimleri ve kullanımlarına kadar hissedilmektedir. Bu süreç içerisinde aynı yüzyılın ikinci yarısı ile beraber resim sanatında çeşitlilik artmış olup, belirli bir üslubun benimsenmesi yerine, içsel temelli espresif şekiller kendisini göstermeye başlamıştır. Bu şekilde ilk soyut yaklaşımlı modern çalışmaların başlamış olduğunu söylemek mümkündür (Aslanapa, 2007).

1950 yıllarının başında özgürlükçü demokrasi anlayışının, Türkiye'deki sanat hayatına Batı' daki sanat yeniliklerini ve akımlarını direkt olarak takip eden bir bakış açısı getirmiş olduğu dikkat çekicidir. Bu dönemde Türkiye'de resim soyut akımların etkisi altına girmeye başlamıştır. İlgili dönemin ardından Türkiye'de pek çok ressam soyut sanat anlayışını benimsemeye başlamıştır. Zaman içerisinde Batılı çizgilerle geleneksel çizgiler iç içe geçerek ortaya farklı ifadeler çıkmıştır. Özellikle Nebati çizgilerin çok fazla görüldüğü soyut resim tarzlarından o dönemde ortaya çıkan türün adı Lirik Soyutlamadır (Tansuğ, 1986; s. 246).

Ressamın bilinçaltı yansımalarından oluşan resimler lirik soyutlama içerisinde değerlendirilmektedir. Belirli bir şiirsel tema içerisinde ressamın bilinçaltının malzemeler ile uyumlu bir şekilde tuvale yansıması bu tarzın çekirdeğini oluşturmaktadır. Lirik Soyutlama tarzını temel alarak sanatlarını icra eden ressamlar için önemli görülen, ressamın çevresinde bulunan görüntülerin ötesinde hayal gücünün vurgulanmasıdır. Ressam kendi iç dünyasından hareket ederek, resmin başı ve sonunun sürpriz bir şekilde biçimlendiği şeyleri resme dökmektedir (Turani, 1999). 
Lirik soyutlama tarzının çıkış noktasını doğadaki motifler oluşturmaktadır. Özellikle de Nebati motifler bu tarzı kullanan ressamların resimlerinde çokça görülmektedir. Bununla beraber, doğadan bir görüntünün yanında, bir çocuk, renkli nesneler ya da bir kadın da görüntülere eşlik edebilmektedir. Bu tarz bir diğer ifadeyle dışarıdaki dünyadan herhangi bir çıkış noktasını aramadan hayal dünyasının direkt olarak tuvale yansıması şeklinde de ifade edilebilmektedir. Burada önemli olan resmin belli bir ekspresyon içeriyor olmasıdır. Bütün ressamların kendisine has bir renk paleti bulunmaktadır. Bunun yansitılmasıyla lirik soyutlama ortaya çıkmış olmaktadır. Özellikle Zeki Faik İzer (Resim 1) ve Abidin Dino (Resim 2) bu alanda dikkati çeken iki Türk ressamdır.

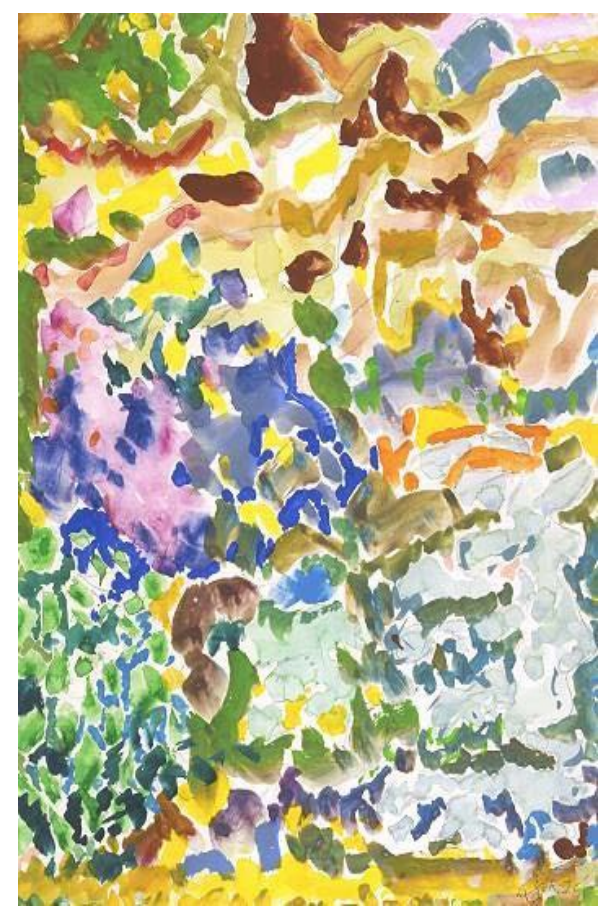

Resim 3. İzer, "Bahçede Çiçekler" 61.5049 X 35 cm, Kağıt Üzeri Guaj. 


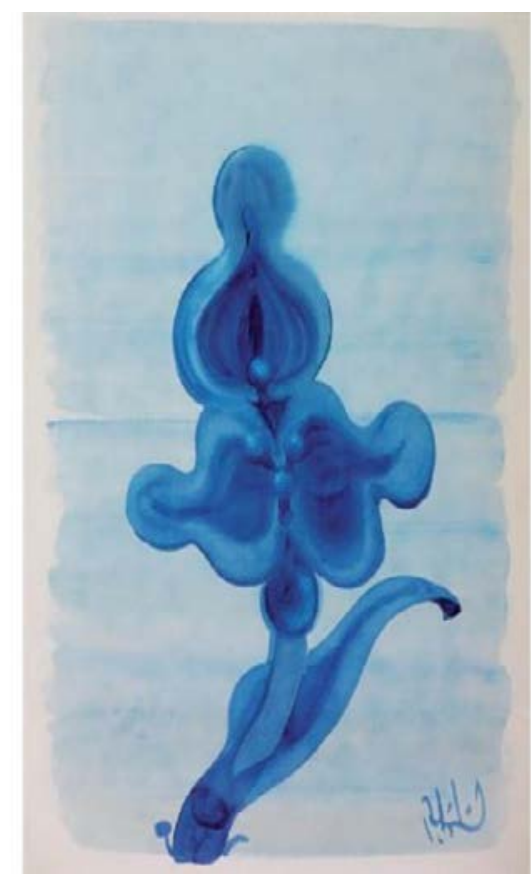

Resim 4. Abidin Dino, "Çiçek”, 82 x 61.50 cm, Kağıt Üzerine Guaj.

Modern soyut Türk resmine nebati motiflerin etkileriyle ilgili olarak Eliri,

"Çağdaş Türk Resim Sanatının Gelişimine Etki Eden Faktörler" başlıklı bildirisinde, çağdaş Türk resim sanatımızın gelişiminde önem arz eden unsurları siralarken birinci sırada, - geleneksel sanatların ve minyatür sanatının çağdaş Türk resim sanatına katkısı, en son sırada da -düzenlenen müzayedelerin katkısı olarak vermiştir. $\mathrm{Bu}$ sıralama tarihsel ve toplumsal gelişime paralel olarak, Türk resminin ilk kaynaklarından yola çıkılarak yapılmıştır. Türk resminde, Batılı tarzda resim yapma 200 yıla yaklaşan bir süreyi kapsamasına rağmen, daha köklü geleneksel sanatların ve minyatür resim sanatının Türk resim sanatına katkısı, Batı sanatının katkılarının yanında günümüze dek dönüştürülerek devam etmektedir. "Bir önceki kuşağın bir sonraki kuşağa aktarıldı̆̆ görsel değerler süreklilik gösterir ve yeni değerler ancak bu süreklilik içinde belli bir yere oturtulabilir.”

ifadelerini ortaya koymuştur (Eliri, 2010: 298)

Avrupa'nın yeniliği öne çıkarak soyut resim anlayışı temelinde şekillenen modern Türk resim sanatının, geleneksel estetiği önemseyen halkın benimsemesi 
sanıldığ kadar kolay olmamıştır. Bu yüzden İstanbul'da yapılan ilk modern soyut sergisinde 20 ressam, konuyla ilgili halka çağrıda bulunmuşlar ve bildiride şu ifadelere yer vermişlerdir; "Sizin yeni resmi yadırgayacağınızı sanmıyoruz. Yeni resmi yadırgayanlar, resmin yalnız bir tür benzetmeci olması gerektiğine karar kılmış olanlardır. Halbuki Karagözü, yazmayı, kilim nakışlarının türlü türküsünü bilen sizler, resmin her çeşidini anlayacak, sevecek kadar zengin bir mirasçılarısını"" (Tansuğ'dan aktaran, Karaduman, 2001: 20). Bu ifadelerde aslında soyut resmin halk tarafindan kabul edilmesiyle ilgili duydukları kaygıyı, geleneksel biçim dünyasına çağdaş sanat dünyasını göstererek ortadan kaldırmayı amaçlamışlardır.

Modern Türk resim anlayışında ortaya çıktığından itibaren, geleneksel şekilleri modern bir çizgiyle tekrar sunmak bulunmaktadır. Fakat bu düşünce belirli bir dönem yetersiz görülünce ressamlar bir dönem gelenekseli tamamen bir tarafa bırakıp Batı resim anlayışını temel almışlardır. Çünkü eski dönemde kullanılan süslemeler, bezemeler ve motifleri soyut bir bakış açısıyla, yalnızca biçimsel şekilde tuvallerine aktarmış olan ressamlar o dönemde eleştirilerden nasibini almıştır. Halk sanatıyla modern Türk resminin arasında bulunan ilişkiyi daha çok yaşamsallık, kaynaştırma ve bunun sonucunda senteze dayandıran Bedri Rahmi Eyüboğlu tarafindan yapılmış olan resimlerde geleneksel formların yeni bir bakış açısıyla başka bir şekilde biçimlendirilmiş olduğu dikkati çekmektedir.

Endüstrinin öne çıktığı dönemde, Avrupalı ressamların arasında hızlı bir şekilde yaygın hale gelen modern ve postmodern “özgün” ve "özgür” eğilimlerin bir sonucu olarak "yeni akımlar" şeklinde aranan çıkışın ve arayışların önemli seviyede Uzakdoğu ve Ortadoğu yerel ve geleneksel sanat motifleri arasında son bulduğu ifade edilmektedir. Bilhassa soyut resmin temelini Doğu'nun mistik havası, motifleri, şekilleri, stili ve bakış açısı oluşturduğu için Batı'nın resim sanatında yüzey araştırmasında bulunan pek çok ressamında Doğu'da ki geleneksel ve yerel kültürleri incelemiş oldukları ve çalışmalarının tasarımı esnasında bunlardan faydalandıkları pek çok örnekle ortaya koyulmaktadır. Hatta bunların arasında en fazla dikkati çekenlerden biri de Paul Klee'nin resmidir. Dolayısıyla modern soyut Türk resminin de Osmanlı mimarisindeki nebati motifleri kullanması ve bunların harmanlamasıyla soyut resimde yeni bir çığır açılmış olması tesadüf değildir. Geleneksel temellerin soyut resimde kullanılması Türkiye'den önce Batı' da görülmüş olup zaman içerisinde Türk ressamların da kendi geleneksel formlarını temel alması artış göstermiştir (Bal, 2010).

Geçmişten günümüze modern soyut resimde pek çok ressamın nebati motifleri kullandığı dikkati çekmektedir. Özellikle bunun en öne çıkan örneğini en yakın tarihte kendi Yüksek Lisans tez çalışmasında gösteren Tuğçe Diri (2019), modern soyut resmi alanında bulunan resimlerinde, geleneksel değerleri ön plana çıkarmaktadır. Özellikle de Türk-İslam kültürü, doğayı ve insanı öznel 
yorumlardan uzak tanıyabilme gereksiniminin ötesinde onu temsilini yapmış olduğu soyut manaya yöneltmesi esnasında çeşitli sanat pratiklerini de geliştirme imkânı bulmuştur. Söz konusu pratikleri uygulama esnasında titizlik ve sabırla çalışmış olan Tuğçe Diri'nin temelde bundan beslenmiştir. Resimlerinin temelinin geleneksel tezhip sanatı oluşturan Diri, resimlerinde doğayı tasarlarken motif temelli öğeleri kullanmakla beraberi doğayı kendi gerçekliğinin dışında sembolik bir şekilde ele almaktadır. Tuvallerinde ana form olarak Osmanlı mimarisinde kullanılan nebati motifleri alarak, soyut zeminlerin üzerinde anlık bir refleksle geçirip, kültürel alt yapının somutlaştırılmasına adeta bir örnek oluşturmaktadır.

\section{SONUÇ}

Belirli bir coğrafyanın parçası şeklinde gelişmiş olan tarihi birikim bugünün yaşamını aydınlık hale getirdiği için oldukça anlamlı görülmektedir. Türk toplumunun kendisinin tarihi süreçlerinin içerisinde oluşturmuş olduğu geleneksel sanatlar, hem Türk kültürü ve sanatsal bakış açısının ifade edilmesi açısında oldukça önemlidir. Toplumsal yapı şartları içerisinde gerçekleştirilen sanat eserleri, özel bir sentezle, belirli yapı stillerine, resim konularına, malzemelere ve motiflere dönüşmektedir. Osmanlı mimarisinde kullanılan Nebati motifler tam da böyle bir konuma sahiptir.

Mimari içerisinde öne çıkan ve çeşitli tipleri, tarzları olan nebati motifler zaman içerisinde soyut Türk resmine girmeye başlamıştır. Nebati yani diğer bir ifadeyle bitkisel temaları içeren bu motifler, Osmanlı mimari eserlerinde özellikle bir döneme damgasını vurmuş olup pek çok mimari eserde karşımıza çıkmaktadır. Bununla beraber yalnızca mimari alanda değil tezhip ve hat gibi Osmanlı dönemi sanatsal eserlerinde de nebati motiflere rastlamak mümkündür.

Türk resim anlayışı Cumhuriyet'in de ilanıyla modernleşme yoluna gitmiştir. Modernleşme adı altında ilk olarak Avrupa' ya giden Batılı ressamlar, Batı tarzını benimseyip özellikle bir dönem geleneksel motiflerden uzaklaşmışlardır. Fakat zaman içerisinde Türkiye'de soyut resmin de gelişmesiyle modern eserlerde geleneksel temalar görülmeye ve adeta bir sentez oluşturmaya başlamıştır. Hatta günümüzde dahi pek çok soyut çalışmalar yapan ressamlar nebati motifleri ve daha bunun gibi pek çok geleneksel öğeyi resimlerinde kullanmakta ve onlara yeni bir soluk getirmektedir.

\section{KAYNAKÇA}

Aslanapa, O. (2007). Türk Sanatı. 8. Bask1, Remzi Kitapevi.

Bal, A. (2010). Geleneksel Türk Sanatlarının Batı Soyut Resim Sanatının Temellendirilmesindeki Rolü. IV. Uluslararası Türk Kültürü ile Sanatları 
Kongresi/Sanat Etkinlikleri, 02-07 Kasım 2009, Kahire, Selçuk Üniversitesi Selçuklu Araş. Mer. Yayını, Bildiriler Kitabı.

Birol, İ. A., ve Derman, Ç. (2004). Türk Tezyini Sanatlarında Motifler. Kubbealtı Akademisi Kültür ve Sanat Vakfi.

Bulut, M. (1994). Ince Minareli Medresenin Portal Minare ve Kubbesindeki Dekoratif Süsler, S. Ü. Eğt. Fak. Resim-iş Eğt. Böl. Bitirme Tezi, Konya.

Çalıkoğlu, L. (2008). Çağdaşs sanat konuşmaları. 3, 90 'l y yllarda Türkiye'de çağdaş sanat. Yapı Kredi Yayınları.

Demiriz, Y. (1979). Osmanl mimarisinde süsleme, I Erken Devir (1300-1453). Kültür Bakanlığı.

Duben, İ. (2007). Türk resmi ve eleştirisi: 1880-1950. İstanbul Bilgi Üniversitesi Yayınları.

Eliri, İ. (2010). Çağdaş Türk Resim Sanatının Gelişimine Etki Eden Faktörler. IV. Uluslararası Türk Kültürü ile Sanatları Kongresi/Sanat Etkinlikleri, 0207 Kasım 2009, Kahire: Selçuk Üniversitesi Selçuklu Araş. Mer.Yayını, Bildiriler Kitabi.

Gültekin, G. (1992). Batı anlayısında Türk resim sanatı. Ziraat Bankası.

Güney, Z., N. (2002). Osmanlı Süsleme Sanatı. SFN Ltd. Şti. Yayıncılık.

Gürsu, N. (1988). Türk dokumacıllk sanatı: Çağlar boyu desenler. Redhouse Yayınları.

Karaduman, A. (2001). Çağdaş Türk Resminin Geleneksel Estetik ve Biçim Anlayışıyla Olan İlişkisi Bağlamında Resimde İstif Sorunu. D.E.Ü G.S.F Resim Böl. Lisans Tezi, İzmir.

Kayapınar, U. (2013). Soyut Ekspresyonizm - Otomatizm İlişkisi. Mimar Sinan Güzel Sanatlar Üniversitesi, Sosyal Bilimler Enstitüsü, Resim Anasanat Dalı Basılmamış Sanatta Yeretlik Eser Metni, İstanbul.

Tansuğ, S. (1986). Çăgdaş Türk sanatı. Remzi Kitabevi.

Turani, A. (1999). Çağdaş sanat felsefesi. Remzi Kitabevi. 